\title{
A Stylistic Analysis of some Selected Poems of Wystan Hugh Auden's War Poetry: A Foregrounding- Backgrounding Approach
}

\author{
Dr. Hanaa Mohamed Helmy El-Gindy \\ Lecturer in the Faculty of Education \\ Mansoura University
}

\section{Abstract}

This research paper offers a stylistic analysis of some selected poems of Wystan Hugh Auden's war poetry. It focuses on four major poems: 'O What is that Sound', 'Danse Macabre', 'Spain 1937' and 'September1, 1939'. These poems represent the period of the thirties of the twentieth century. The research shows how Auden skillfully uses the foregrounding-backgrounding approach in presenting his poems. In so doing, the researcher uses the following theoretical framework: simple repetition, parallelism and deviation. The research paper investigates mainly these levels of linguistic deviations: discoursal, grammatical and graphological, morphological and lexical, and semantic. The researcher concludes that Auden is a great poet because his poems could keep him alive even after his death. His poetry still needs a lot of work.

Key Words: Stylistics, W. H. Auden, Foregrounding, repetition, parallelism and deviation.

$$
\begin{aligned}
& \text { بعرض هدا البحث تحليل أسلوبي لبعض قصائد الحرب للشاعر ويستان هيو أودن. بركز البحث }
\end{aligned}
$$

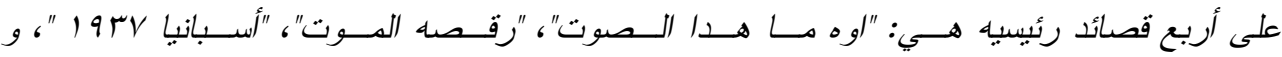

$$
\begin{aligned}
& \text { "سبتمبر 9ه } 9 \text { ا ، ا". تمثل تلك القصائد فتره الثلاثينيات من القرن العثربن. بوضح البحث كيفيه الاستخدام } \\
& \text { الهاهر لأودن لأسلوب الوضع في المقدمه والخلفيه في عرضه لقصائده. وفي هدا الثأن ببتخدم الباحث } \\
& \text { الاطلار النظري التالي: النكرار البسبط، التهائل، و الانحراف. بيتاول البحث المستويات التاليه للانحرافات } \\
& \text { اللغويه: الخطاب، القو اعد و الجرافولوجيا أو الخط، تركيب الكلمه و المفردات، و المعاني. و يخلص الباحث }
\end{aligned}
$$

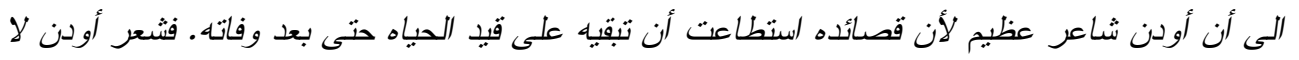

$$
\begin{aligned}
& \text { بز ال بحاجه لمزيب من الدراسه. } \\
& \text { كلمات مفتاحيه: أسلوبيات، أودن، الوضع في الدقدم، التكرار، التماثل، و الانحراف. }
\end{aligned}
$$




\section{Introduction.}

This research paper offers a stylistic analysis of Wystan Hugh Auden's war poetry and in particular those poems written in the thirties before his migration to America in the forties of the twentieth century. In so doing, it concentrates on four major poems: 'O What is that Sound', 'Danse Macabre', 'Spain 1937' and 'September 1, 1939'. These poems are highly representative of that troublesome period and its general moods of anxiety, fear and uncertainty. Although W. H. Auden is classified as a war-poet, yet the researcher's selection of him is due to the fact that his poems are considered as 'anti-war poems'. They are not summons of people for military service. Rather, they condemn war and call for peace and love.

W. H. Auden (1907- 1973) was an English middle-class poet of the twentieth century. He was one of the spokesmen of his age. He belonged to the War Generation who witnessed the First World War (1914- 1918) and was destined to expect the outbreak of the Second World War (1939- 1945) also. He was one of the most versatile and prolific poets of his time. He regained his fame after his death and in particular after the incidents of September $11^{\text {th }},(2001)$ in America. At that time, two terrorist planes crashed the World Trade Centre and the Pentagon. These incidents brought his poem 'September 1, 1939' back to life as they occurred in the same month. This recalled Auden's view of the immortality of the poet through his language. He stated that "the death of the poet was kept from his poems" ('In Memory of W.B. Yeats' CP. 49). For Auden, the poem is what remains; it is the thing that keeps the poet alive after his death.

The thirties was not a classic period of stability, tranquility and ease. It was a "low dishonest decade" as Auden labelled it in "September 1, 1939' (CP.1976: 57). It was a period of conflicts everywhere in the whole wide world. It started with the beginning of the Depression in the United States of America in (1929) and the Slump in the United Kingdom in (1930). It witnessed Hitler's coming to power in Germany in (1933) and the spread of Nazis. It saw the Civil Wars in China and Spain. In (1935) Mussolini, the Italian Fascist, invaded Ethiopia. The sparkle of World War II started by Hitler's invasion of Poland on September 1, 1939. England and France, as allies with Poland, declared war on Germany, which was in alliance with the Soviet Union, Italy and Japan on September 3, 1939. Poland was defeated and divided between Germany and the Soviet Union. At the beginning the United States of America was not participating in war; it was attempting to remain neutral. But later on, it became involved also.

\section{I.Theoretical Preliminaries.}

Stylistics is a branch of applied linguistics. It offers a linguistic study of texts in general and literary texts in particular. It presents a linguistic toolkit relevant to the 'description', 
'interpretation' and 'evaluation' of the texts (Short, 1996: 3). This objective evaluation can either support or refute the analysis done by literary critics because it is based on linguistic facts. Stylistics lays specific emphasis on 'deviation' and 'foregrounding'. Deviation occurs as a result of the breaking of the rules of language or a specific genre. It affects the psychology of the readers and the hearers. Short (1996: 11) calls this psychological effect 'foregrounding'. The origin of 'foregrounding' goes back to Viktor Shiklovsky who called it 'defamiliarization' or 'dehabitualization'. Then Jan Mukarovsky named it 'foregrounding' (Fowler, 1981: 20). The Deviated or marked parts of the text are put in the foreground. Whereas the normal undeviant or unmarked parts of the text remain in the background. Deviation occurs at different linguistic levels: discoursal, grammatical, graphological, morphological, lexical, semantic and phonological. Foregrounding could be achieved through simple repetition, parallelism and deviation. Studying the recurrent patterns of foregrounding enhances the readers' appreciation of the literariness of the texts they are reading.

\section{I.1. Simple Repetition and Parallelism.}

As its name suggests, 'simple repetition' occurs when one word or whole structures are repeated (Short, 1996: 14). 'Parallelism' deals with repetition but in a different manner. Some linguistic patterns or structures are repeated while lexical or idiomatic items are varied (ibid: 14). Parallel structures trigger the readers to ask about the meaning connections between the varied parts.

\section{I.2. Deviation.}

\section{2. a. Discoursal Deviation.}

Whenever people speak, they produce utterances that range from one sound to a group of sentences. Discourse can be any form of spoken language, e. g. a conversation, an interview, a drama text, a lecture, etc. Participating in discourse means to transcend beyond the level of the sentence and to proceed to higher levels including the participants, their relationships, the system of turntaking between them, the topics they handle, the way they begin and end their talk. Generally speaking, speakers or addressers tend to begin their discourses at the beginning of sentences and end them at the end as well. But when this does not happen, we say that there is an instance of discoursal deviation. Consider for example the first poetic line of a poem that begins with the word 'Yes'. Generally speaking, this 'Yes' should be an answer of a 'Yes or No' question; its normal undeviant use should be as a second pair part of an adjacency pair. But when the first pair part of the adjacency pair is absent, as in this example, we say that there is discoursal deviation. It sets the readers in the mood of a conversation where the participants are interacting and negotiating together. Also the typical pattern of relationship between the poet and his readers in poetry is 
that the poet addresses a message to the addressees. But when there is more than one addresser or addressee, the discourse situation becomes deviant.

\section{I.2. b. Grammatical Deviation.}

Grammar refers to the knowledge of the rules of language that the users must have in order to produce well- formed structures. It deals with the arrangement of words in order to get a syntactically correct sentence. It helps us study things such as word- order, definiteness and generics, and tense. Also, it offers information about the use of articles and their significance. Moreover, it tells us whether the verb is finite or non- finite. On one hand, finite verbs carry information about tense, modality and aspect (Thornborrow and Wareing,1998: 67). The tense of the verb shows its time, past or present. The mood of the verb "gives information about a speaker's attitude towards [his] utterance" (ibid: 66). And the aspect of the verb "indicates whether an action or state of affairs is completed or not" (ibid: 66). On the other hand, non-finite verbs do not carry information about the tense, mood or aspect of the verb. These non- finite verbs can be in one of these forms: an infinitive, e.g. 'to see', a gerundive, e.g. 'seeing', or a past participle, e.g. 'seen'. Grammatical deviation is another device used by writers to achieve foregrounding. Deviant grammatical structures are put in the foreground and normal ones remain in the background. Grammatical deviation occurs when the writer breaks the rules of language through 're- ordering' or 'resequencing'(Short, 1996: 48); the overuse of punctuation marks or the complete loss of them; and 'ellipsis' which is the omission of an item that can be implicitly understood (Toolan, 2002: 27). Thornborrow and Wareing (1998: 76) talked about 'ellipsis' also but they labelled it 'disruption'.

\section{I.2. c. Graphological Deviation.}

Graphological deviation is related to the way words are written down on the page. It appears in different forms including: the splitting up of words into single identifiable syllables; the absence of normal spacing and punctuation between words (Short, 1996: 56); and capitalization. Phonetically speaking, capitalizing all the letters of the word makes it more salient. It affects the way the readers will pronounce it. They will pronounce it with more power and force and this will put it in the foreground.

\section{I.2. d. Morphological Deviation.}

Morphology deals with the grammar of word formation. It checks whether the word consists of a free or a bound morpheme. A morpheme is the smallest meaningful unit in the language. A free morpheme is the one that can stand alone and its meaning is complete in itself. The bound morpheme is the one that needs a free morpheme to stick to, e. g. the word 'brothers' consists of two morphemes: the free one 'brother' and the bound plural 's'. Also morphology checks whether the free morpheme belongs to an open- class of words or a closed 
one. Open- class words are called lexical morphemes; they are nouns, verbs and adjectives. They are lexically heavy as they are meaningcarrying words. They accept the piling- up of affixes. Closed- class words are called functional or grammatical morphemes. They do not accept any kind of piling up of affixes. Short (1996: 51) points out three ways of achieving morphological deviation. Firstly, by adding an ending to a word it wouldn't normally be added to. Secondly, by separating morphemes off as quasi- separate words. And thirdly, by running more than one word together as if they were one. The point here is that a keen scrutiny of morphological deviation shows that it is integrated with the other linguistic levels. In fact we cannot draw a clear cut line that separates the various types of deviation from each other. They are all intermingled.

\section{I.2. e. Lexical Deviation.}

As mentioned before, words fall into two groups, grammatical and lexical. The importance of this grouping lies in the fact that "the more compressed a style is the more likely it is to abandon grammatical words" (Blake, 1990: 52). This is exactly what happens in poetry where lexical words are kept at the expense of grammatical words. Hence, more density of meaning is realized. Lexical deviation arises as a result of borrowing, neologism, functional conversion or shift and the archaic or obsolete use of words. 'Borrowing', as its name suggests, is the introduction of a word from another language into English. 'Neologism' is the invention of a word that did not exist before. This invention can be done through compounding. Compounding is one of the most important ways of producing deviant or exotic words. It arises as result of the combination of two free morphemes, e.g. 'housewife'. The meaning of the resulting word is totally different from the meaning of each separate component. So, compounding deals with the form of the word. Whereas functional conversion deals with its function. Short (1996: 45) defines functional conversion as "the process of converting one grammatical class into another". Blake (1990: 57) called it "functional shift". The archaic or obsolete means "the unusual meaning of a word" (Freeborn, 1996: 253). This archaic use of unusual word meaning violates the norms of language and produces lexical deviation.

\section{I.2. f. Semantic Deviation.}

Semantic deviation happens when there are inconsistent meaning relations. Metaphors represent a striking example of semantic deviation. For once readers are unable to perceive the literal meaning in front of them, they are required to search for the metaphorical one.

\section{I.2. g. Phonological Deviation.}

Phonology is a branch of linguistics that studies the sounds in a specific language. The minimal unit of phonology is the phoneme. A phoneme is the sound that 
distinguishes one word from another, e. g. 'sit' and 'bit'. Analyzing literary texts and in particular poetry, one cannot do without phonology. For what defines poetry is its sound pattern. Thornborrow and wareing (1998: 25-32) state that there are different forms of sound patterns including: alliteration, assonance, consonance, internal rhyme, reverse rhyme, pararhyme, repetition, rhythm and metre. The following two lines from 'The Passionate Shepherd' by Christopher Marlow embody most of the different types of sound patterns.

"Come live with me and be my love And we will all the pleasures prove"

Alliteration is the similarity between initial single consonants or consonant clusters, e.g. 'me' and 'my'. Assonance occurs when syllables share the same vowel sound, e. g. 'come' and 'love'. Consonance happens between words whose final consonants are identical, e. g. 'will' and 'all'. Rhyme takes place when two words share the same final vowel or consonant sound, e. g. 'me' and 'be'. Rhyme can be internal, reverse, pararhyme, or repetition. Internal rhyme occurs between rhyming words in the same poetic line, e.g. 'me' and 'be'. Reverse rhyme happens between words sharing the same initial consonant and vowel, e. g. 'with' and 'will'. Pararhyme arises between words that are identical in everything except the vowel sound in the same position, e. g. 'love' and 'live'. And repetition is to rewrite the word as it is. Rhythm and metre are always identified in terms of stress patterns.
Stress is the degree of force or power by which speakers pronounce a syllable. Syllables are either stressed or unstressed. The organized distribution of syllables in a poem to fit a specific stress pattern or rhythm creates its metre. And a single unit of metre is called a foot. The poetic line is named according to the number of metrical feet it has. If the line has only one foot, it is called monometre. If it has two feet, it is called dimetre. If it has three, it is trimetre; etc...

To recap, the study of sound patterns in a poem draws the attention of its readers to its aesthetic parts. Also, the recurrence of the forementioned phonological sound patterns puts some words in the foreground and leaves the rest of words in the background. This triggers readers to think about the causes behind this salience.

\section{Theoretical Framework.}

This paper attempts to offer a stylistic analysis of the following four poems by W. H. Auden: 'O, What is that Sound', 'Danse Macabre', 'Spain 1937' and 'September 1, 1939'. In so doing, the researcher uses the following theoretical framework: simple repetition and parallelism, and deviation. The researcher deals with the following levels of linguistic deviation: discoursal, grammatical and graphological, morphological and lexical, and semantic.

\section{Research Questions.}

The paper attempts to answer the following questions:

1. What is the role of stylistics in the interpretation and assessment 
of Auden's war poetry and in particular ' $\mathrm{O}$, What is that Sound', 'Danse Macabre', 'Spain 1937' and 'September 1, 1939'?

2. What is the impact of simple repetition and parallelism as foregrounding devices on the understanding of the poems?

3. What is the significance of discoursal deviation in directing readers' minds towards salient points in the poems?

4. How can grammatical and graphological deviations uncover hidden meaning relationships in the poems?

5. Why does the poet use morphological and lexical deviations in the poems?

6. How can semantic deviation solve nonsensical paradoxical relations and render them meaningful?

7. How are the various levels of linguistic deviation integrated together?

\section{Objectives of Research.}

The paper has the following objectives:

1. Studying the role of stylistics in enhancing the interpretation and assessment of Auden's poems.

2. Identifying the effect of foregrounding through simple repetition, parallelism and deviation on the readers of the poems?

3. Discussing the functions of the various levels of deviation, namely discoursal, grammatical and graphological, morphological and lexical, and semantic, in achieving foregrounding as opposed to backgrounding in the poems.

\section{Analysis of Data:}

\section{V.1. 'O What is that Sound'.}

The poem was written in (1932) and published in (1934). Its historical context is not known. But it is clear that it is about people who live in a country in a time of war. It is about a married couple staying at home and questioning about the sound they are hearing down in the valley. As the poem proceeds, we get to know that the sound is that of soldiers coming to this couple to arrest the husband and harass the wife. So, the husband betrays his wife and decides to escape. He leaves her alone to face this horrible situation. The poem pictures the feeling and behavior of people in war time.

\section{V.1. a. Simple Repetition and Parallelism in ' $O$ What is that Sound'.}

This poem is mainly based upon simple repetition and parallelism. The interjection ' $\mathrm{O}$ ' is always repeated at the beginning of each stanza. Also, the second line in each stanza includes simple repetition. The wife always repeats the last word in her question twice, e.g. 'drumming, drumming?', 'brightly, brightly', 'wheeling, wheeling', 'their horses, their horses', etc... . Also, 'perhaps', a word indicating doubt, is repeated twice. But when the speakers became certain of the coming danger, they repeated the word 'must'. Of course, the 
normal pattern is to mention anything only once. But this repetition has a foregrounding effect. It reflects the wife's sense of perplexity and astonishment.

The poem also proceeds through parallelism. Many linguistic structures are held constant while the lexicon becomes different. Examples: 'what is that sound' and 'what is that light', 'haven't they stopped', and 'haven't they reined', 'broken the lock' and 'splintered the door'. The wife spoke about the soldiers in a way that makes us know that they are on their way to her. Parallelism helps us make links between 'broken' and 'splintered' on one hand and the 'lock' and the 'door' on the other hand. So, we get to know that these soldiers are violent and aggressive. They do not belong to the same side of the couple. Rather, they belong to the different side.

\section{V.1. b. Discoursal Deviation in ' $O$ What is that Sound'.}

The poem is written in the form of a conversation between two persons none of whom is the poet. This is a discoursal deviation because the standard discoursal situation is that of a poet addressing the listeners. The pattern of the first seven stanzas is that of an adjacency pairs; they are all questions followed immediately by their answers. Adjacency pairs are one of the most important structural features of conversational discourse. They are two pair parts that the presence of the first pair part makes the presence of the second pair part a must. In this poem, the first pair part is produced by the wife. And the second pair part is produced by the husband. Look at the following examples:

Q1: "O what is that sound... ?"

A1: "Only the scarlet soldiers, dear,"

Q2: "O what is that light...?"

A2: "Only the sun on their weapons, dear,"

Q3: "O what are they doing... ?"

A3: "Only their usual manoeuvres, dear,"

Q4: "O why they have left the road down there...?"

A4: "Perhaps a change in their orders, dear." $\quad(C P, 1976: 222)$

Starting from the fourth stanza, we perceive the change in feelings. The husband follows his answer with a question to his wife. He asks her "Why are you kneeling?" But this question goes unanswered. It is left to us as audience to infer why? May be she kneels because she wants to hide. Or, may be she wants to see better. Or may be she prays for God to save them. Then the poem goes back to the previous pattern of a wife asking and a husband responding till stanza eight. At this point a remarkable change occurs.

Q8: "O where are you going? Stay with me here!"

Q9: "Were the vows you swore deceiving, deceiving?"

A9: "No, I promised to love you dear,"

A8: "But I must be leaving." $(C P, 1976: 222)$ 
Times of stress uncover peoples' real personalities. They change as a result of the pressure of war time. The man decides to escape alone. Realizing his intentions, the wife follows Q8 with Q9. She also includes an imperative command, for the first and last time in the poem, between the two questions. The husband neglects her first question, Q8, and refuses to comply with her request. Then stanza nine, which is the last one, proceeds in a different form. Adjacency pairs are not used anymore. The wife uses declarative statements to describe the terrible siruation she is in. For now the soldiers are in her room.

\section{V.1. c. Grammatical and Graphological Deviations in ' $O$ What is that Sound'.}

The poem is replete with instances of ellipsis or disruption. Auden behaves likewise to reflect the general mood of fear. In war time people use lexical words at the expense of the grammatical ones for the sake of brevity. In the first stanza for instance, the man says to his wife: "The soldiers coming". He deletes the finite verb 'are'. It should be 'The soldiers are coming'. Also, he says to her: "Or perhaps a warning". He deletes the subject and the verb. It should be: 'Or perhaps it is a warning'. Also the poet uses inversion as the wife says: "It must be the farmer so cunning". It should be "It must be the so cunning farmer'. And in the last stanza, the use of the pronoun 'it' is highly indicative. The wife uses 'it' instead of 'they' to refer to the soldiers. She says: 'O it's broken the lock and splintered the door'. This reflects her confusion and fear.

Regarding the graphological deviation, it is presented through the overuse of the capital letter "O"; whenever it shows up, it is always at the beginning of the poetic line. As an open back vowel, this sound is associated here with anxiety. In this context, it makes us see people putting their hands upon their open mouths and crying for help.

\section{1. d. Morphological and Lexical Deviations in ' $O$ What is that Sound'.}

This type of deviation is depicted through the archaic use of the interjection "O". It reflects the mood of the conversation. Also the poet uses functional conversion so many times in the poem. In so doing, he made the verbs serve the functions of nouns, adjectives and adverbs. Look at the following lines:

"The soldiers coming.

As they step lightly.

And now they are running.

O it's the gate where they're turning, turning;

Their boots are heavy on the floor

And their eyes are burning" (ibid)

As shown above, Auden's description of the soldiers is amazing. Firstly, the soldiers are coming. 
Secondly, they march fast with energetic military light steps. Then they run towards their target, the gate. They have heavy boots on their feet. They enter the room and their eyes are burning with anger.

\section{1. e. Semantic Deviation in ' $O$ What is that Sound'.}

Semantic deviation makes us think of inconsistency in meaning. The wife describes her husband's vows of marriage as "deceiving". She also speaks about the farmer as "cunning". And she says that the soldiers' eyes are "burning". Of course all these attributes are semantically deviant. For the vows are inanimate and the verb deceive requires an animate subject. Also, she describes the farmer as cunning although he did not bother or hurt her at all. She did so only as an attempt to justify the cause behind the coming of the soldiers. She has a wish that they are coming to arrest the cunning farmer. And the soldiers' eyes are not meant to be burning really. Such a description shows that the soldiers are very angry to the extent that their eyes looked burning with fire.

\section{VI. 'Danse Macabre' and 'Spain 1937'.}

Both of 'Danse Macabre' and 'Spain 1937' were written in 1937. Their historical context is that of the Spanish Civil War where "matters are settled with gas and with bomb" ('Danse Macabre', in ibid: 59). And that is why the researcher prefers to discuss them together. In 'Danse Macabre', the poet speaks to his wife and comments on the political incidents around them and their repercussions. He tells her that if people want to change and improve their life, they have to start working on themselves. He, himself, as an active individual, will take this responsibility. Also, in 'Spain 1937', he stresses the same view of the role of the individual in his society. He calls for his talent as a poet to help him. He says: "O my vision. $\mathrm{O}$ send me the luck of the sailor" ('Spain 1937', in ibid: 182).

VI.a. Simple Repetition and Parallelism in 'Danse Macabre' and 'Spain 1937'.

There are many instances of simple repetition and parallelism in these two poems. Look how he describes the devil in the following lines:

"Like influenza he walks abroad, He stands by the bridge, he waits by the ford,

As a goose or a gull he flies overhead,

He hides in the cupboard and under the bed." ('Danse' in ibid: 60)

Here, Auden repeats the pronoun 'he' several times. This repetition shows that the poet's mind is busy thinking of this devil. Also Auden uses parallelism as he repeats the same structure, 'subject + finite verb+ adverb', but changes the lexicon. Examples are: 'he walks abroad' and 'he flies overhead'. Another structure, 'subject+ finite verb+ prepositional phrase', is repeated also. Examples are: 'he stands by the bridge', 'he waits by the 
ford', and 'he hides in the cupboard'. Then the poet repeats the structure of the prepositional phrase through another prepositional phrase, 'under the bed'. This parallelism puts the devil and his deeds in the foreground. Parallelism affects our interpretation of the poem. It tells us that the whole air is impeded by this devil. The devil is everywhere. Auden uses the word 'Devil' to refer to Hitler who broke his promise. In another stanza, Auden says:

"I shall come, I shall punish, the Devil be dead,

I shall have caviar thick on my bread,

I shall build myself a cathedral for home

.....

I shall ride the parade in a platinum car" ('Danse' in ibid: 61 )

In the first line, Auden repeats the structure 'I+ shall + inf'. First he started with an intransitive verb, 'come'. Then he changes the verb as he says: 'punish' which is a transitive verb that needs an object. But again he does not tell us who shall be punished. He deviates in the structure 'the Devil be dead'. It should be 'the Devil shall be dead'. But he substituted the modal 'shall' with the subjunctive 'be' to express "a desired outcome" (Stageberg and Oaks, 2000: 156). Then Auden returned to the previous structure with the transitive verbs, 'have', 'build' and 'ride'. All this reflects the luxurious life he longs to attain.
In the last stanza, the word 'good-bye' is repeated five times. The first three good-byes achieve the parallel structure 'good-bye + to + noun phrase'. It is good-bye to the 'house', 'sheets' and 'birds'. Then the fourth 'good-bye' occurs in the structural pattern 'it's+ good-bye' which recalls the same structural pattern of the first line in the first stanza in the poem, 'It's farewell'. The significance of parallelism is that it makes the audience compare the different lexicon. The words 'farewell' and 'good-bye' are two synonyms indicating departure and separation. Finally, Auden ends his poem by 'good-bye to you all' which is similar to the structure of the first three in 'good-bye+ to'. But here he substitutes the noun phrase with the pronoun 'you + all'. This foregrounding effect makes us predict a difficult future. There will be hard times.

"So good-bye to the house with wallpaper red,

Good-bye to the sheets on the warm double bed,

Good-bye to the beautiful birds on the wall,

It's good-bye, dear heart, goodbye to you all" ('Danse' in ibid: 61)

Turning to (Spain 1937), There are many instances of simple repetition and parallelism also. The poem is built upon three phrases:

"Yesterday all the past."

"But today the struggle." 
"Tomorrow, perhaps, the future." ('Spain 1937' in ibid: 181)

The word 'yesterday' is repeated thirteen times. It is used to refer to the past history with all its great achievements as well as its failures. Then the word 'today' is repeated seven times. It is always accompanied with 'the struggle'. The repetition of the phrase 'today the struggle' stresses the picture of physical sickness, psychological struggle and suffering 'today'. 'Today', which is the time of the poem, spring 1937, is critical for every one including the poet himself, the scientist, the poor people and the nations in Europe. They all cry for help and invoke the 'life-shaper' or the 'Mover' that might be a 'a dove or a furious papa or a mild engineer' to save them. And the life answers them back: 'I am your choice, your decision: yes, I am Spain'. Parallelism makes us conclude that our 'choice' is our 'decision'. Life tells us that if we want to change our condition in the time being, and 'to build the just City', we have to take the right decision in every part of life. Spain itself is a sick case; the future of Spain depends on today's right choices. But this future is uncertain. Auden repeated the word 'tomorrow' six times only. And it is associated with 'perhaps' to show that the future is still undetermined because of peoples' mischievous acts today. Look at these lines:

"Today the inevitable increase in the chances of death;
The conscious acceptance of guilt in the fact of murder;

Today the expending of powers

On the flat ephemeral pamphlet and the boring meeting." (ibid: 184)

Through Parallelism we get to know that the 'struggle' is equal to the 'increase in the chances of death', the 'acceptance of guilt' and the 'expending of power'. All these things carry negative conditions associated with 'today'. Parallelism makes us put 'yesterday', 'today' and 'tomorrow' on one hand and 'the past', 'the struggle' and 'the future' on the other hand.

VI. b. Discoursal Deviation in 'Danse Macabre' and 'Spain 1937'.

The normal unmarked discourse situation is that between an addresser and an addressee speaking over a specific topic or a given message. In 'Danse Macabre', there are three subject pronouns: 'I', 'you' and 'he'. 'I' stands for the poet or addresser; 'you' stands for his wife, or the addressee; and 'he' stands for the "Devil", or the topic of their discourse. The discourse situation remains normal till stanza twelve where the addresser deviates and uses 'you' in a different way. At this time, it refers to men to rise up and slay the devil. He tells them that these are not his orders. He is just conveying the orders of others. He says:

"For it's order and trumpet and anger and drum

And power and glory command you to come;" ('Danse', in ibid: 61) 
Also in 'Spain 1937', the discourse situation proceeds normally through the first six stanzas. Up till that time, there is only one addresser who is the poet and one addressee who is the audience. But starting for stanza seven, there is a discoursal deviation. The poet confronts us with the voices of the addressers: the poet, the investigator, the poor, the nations and the life. And the life plays the role of the addressee and answers back "I am Spain" ('Spain', in ibid: 182). Then in stanza fifteen, the poet goes back again to the previous normal discourse situation. This multiplicity of voices echoes the many conflicting sides in the Spanish War.

VI. c. Grammatical and Graphological Deviations in 'Danse Macabre' and 'Spain 1937'.

$\begin{array}{ccc}\text { In } & \text { 'Danse } \\ \text { grammatical } & \text { Macabre, } \\ \text { deviation } & \text { appears }\end{array}$ through inversion or re-ordering, ellipsis and the absence of punctuation marks. Auden uses inversion many times. Look at these structures:

" Like influenza he walks abroad, /...

]As a goose or a gull he flies overhead,"

"For me it is written the Devil to chase"

"Day-long and night-long the bells I shall peal"

" You shall leave your breakfast, your desk and your play

On a fine summer morning the Devil to slay." ('Danse', in ibid: 61)
These structures should be: 'he walks abroad like influenza'; 'he flies overhead like a goose'; 'it is written for me to chase the devil'; 'I shall peal the bells day-long and night-long'; and 'to slay the Devil'. The last structure includes ellipsis also. It should be: 'you shall leave your breakfast and $g o$ to slay the Devil'. But the poet deleted the verb 'go' in order to make the structure more foregrounded. Also sometimes, Auden deliberately neglects punctuation marks. Example:

"For it's order and trumpet and anger and drum

And power and glory command you to come;" ('Danse', in ibid: 61)

In these two lines, Auden achieves both grammatical and graphological deviation by the absence of commas between coordinating words and the excessive use of the coordinating conjunction 'and'. Such a style of writing puts these deviant structures in the foreground. We realize that this is not the command of the speaker only; it is a collective agent that includes the poet, order, trumpet, anger, drum, power and glory. The poet also makes use of parallelism through his repletion of the structure 'noun+ and + noun'. This wholeness makes us think of the importance of situation. According to the poet, if you want to achieve glory with its trumpets and drums, your anger should be ordered and powerful. Otherwise, it will be a great mess. 
Auden stresses the role of the individual in saving the society. $\mathrm{He}$ regards himself responsible for that. He uses graphological deviation to represent this idea. He says about himself:

"For I, after all, am the Fortunate One,

The Happy-Go-Lucky, the spoilt Third Son;

For me it is written the Devil to chase

And to rid the earth of the human race."

"My features shall shine, My name shall be Star" ('Danse', in ibid: 60)

The capitalizations of these words, 'Fortunate, One, Happy, Go, Lucky, Third, Son, Devil and Star', is significant for the interpretation of the poem. Although Auden is the really the spoilt third son of his family, yet he has to chase the devil. This is in itself contradictory to the nature of a spoilt son who is always served by others. Now, it is his turn not only to help himself but also to work for others and to clean up the earth of the human race. Hence, he has to fight a double war: one against himself, and the other against the Devil outside. And once he performs these hard tasks, his name shall be 'Star'. Moreover, the word 'Star' is written without the use of an indefinite article. 'Star', as a generic noun, shows that he will be very famous. Afterwards, Auden identified the word 'star' by the definite article 'the'. Look at these two lines:
"The star in the West shoots its warning cry:

'Mankind is alive, but Mankind must die" ('Danse', in ibid: 61)

'Mankind' is capitalized, repeated and written without an indefinite article to support the idea of generics. All mankind must die, including the poet himself who belongs to mankind. And that is why he ends the poem with 'good-bye to you all'.

Turning to (Spain 1937), it manipulates grammatical deviation through ellipsis in a very important way. The poems' three famous refrains, 'Yesterday all the past', 'But today the struggle', and 'Tomorrow, perhaps, the future', are all without verbs. Auden deletes the linking verb 'be'. This grammatical deviation makes Auden's writing a quasitelegraphic one. It's effect upon us as readers is that it makes us focus on the most important words in the poem.

Also, the following stanza includes instances of grammatical and graphological deviations. Look at these lines:

"The stars are dead; the animals will not look:

We are left alone with our day, and the time is short and

defeated

History to the

May say Alas but cannot help or pardon” ('Spain', in ibid: 185)

Concerning grammatical deviation, the sentence 'the animals will not look' is deviant. The verb 
'look' is a linking verb that should be followed by a subject complement. But here nothing comes after it. So, this is an instance of ellipsis. It is left for us to fill such a gap by things like 'calm', 'quiet', 'happy' or 'at it'. Perhaps the interpretation here is that because of the ugliness of the scene, the animals will not be able to look at it. Another grammatical deviation here is the inversion in the last two lines. They should be: 'History may say Alas to the defeated but cannot help or pardon'. Also this last line includes ellipsis. The verbs 'help' and 'pardon' are both transitive ones. They need objects. But here, they are not followed by anything. Again it is our job as readers to fill in the gaps. This last part should be 'History ... cannot help or pardon them.' Auden behaved likewise for the sake of brevity. This conforms to his saying in the previous line that 'the time is short'. Also the word 'Alas' has both grammatical and graphological deviations. The poet capitalized it and did not enclose it between two inverted commas, as it comes after the verb 'say'. Auden did all this on purpose. He broke the rules of language as a means of saying that we are running out of time. Also grammatical and graphological deviation appear through the excessive use of the coordinating conjunctions, 'and' and 'or', and the loss of commas. Look at these examples:

"Intervene. O descend as a dove or
A furious papa or a mild engineer: but descend."

And the life, if it answers at all, replies from the heart

And the eyes and the lungs, from the shops and squares of The city"

in ibid: 183)

Coordination in the first two lines should be: 'as a dove, a furious papa or a mild engineer'. And the third and fourth lines should be: "the heart, eyes, lungs, shops and squares of the city'. Auden writes in this way to show the urgency of the situation. Life is tired from the passiveness of man. It says: "O no, I am not the Mover". And it elaborates: "What's your proposal? To build the Just City? I will." Graphological deviation appears in the poem through the capitalization of words that should be written in lower case forms. The capitalization of the 'Mover' and 'Just City' sharpens the meaning. Life, which we get to know that it is Spain, is our decision to Move on. The proposal is not to build any city. The required job is to build the 'Just City'.

VI. d. Morphological and Lexical Deviations in 'Danse Macabre' and 'Spain 1937'.

Morphological and lexical deviations are frequent in 'Danse Macabre' and 'Spain 1937' through neologism, archaism and functional conversion. In 'Danse Macabre', Auden uses neologism through compounding several times. Consider the following examples: 'farewell', 'drawing-room', frock-coated', 'Happy-Go-Lucky', 'day-long', 
'night-long', 'Mankind', 'wallpaper' and 'good-bye'. He also breaks the norms of morphology and adds the suffix 'to' to the question word 'where' and creates the new word 'whereto'. In so doing, Auden grouped two closed-class words together. Moreover, he shows his mastery of language through the use of non-finite verb forms. He uses them in the infinitive, gerundive and past participle forms. Examples of the infinitive form are: 'to triumph', 'to chase', 'to rid', 'to slay' and 'to come'. And examples of the gerundive and the past participle forms are: 'drawing', 'coated', 'succumbing', 'behaving', 'buying', 'selling', 'eating', 'drinking', 'thinking', 'inspiring' and 'warning'. Such a kind of deviation helps the writer escape mentioning the subject of his verbs. Hence, he shifts the focus to the situation itself. Also, Auden's archaic use of the word 'papa' to refer to God reflects the general mood of uncertainty as a result of the development in science and the retreat in the authority of church. The use of functional conversion appears in a structure like 'the rebel angel'. It should be 'the rebellious angel'. But again such a lexical deviation makes us think more and more about these foregrounded devices.

Regarding 'Spain 1937', Auden follows the same style. He uses compounding several times, e.g. 'trade-routes', 'counting-frame', shadow-reckoning', 'cart-wheels', 'madmen', 'waterfall', 'Mankind', 'Yes-man', 'bar-companion', 'easily- duped', 'fishermen', 'makeshift' and 'candle-lit barn'. Also, he uses nonfinite verbs. Look at the following: 'spreading', 'counting', reckoning', 'bustling', 'refreshing', 'invoking', 'enlarging', 'photographing', 'exploring', 'expending', 'hurting', 'fumbled' and 'defeated'. Again the effect of such a kind of lexical deviation is that it adds to the density of the poem. As for the poet's use of archaism in this poem, it appears through his use of the interjection ' $\mathrm{O}$ ' many times. Also, the reference to God as 'a dove or a furious papa or a mild engineer'. They are all inappropriate in this context.

\section{VI. e. Semantic Deviation in 'Danse Macabre' and 'Spain 1937'.}

Auden manipulates sematic deviation in these poems in a salient way. In 'Danse Macabre', he states that " now matters are settled with gas and bomb". The inanimate subject 'matters' settles things with gas and bomb. Auden assigns himself responsibility to 'chase the Devil' and to 'punish it'. Again the devil is something that does not have a physical existence and hence cannot be chased or punished. The scene is terrible; and the situation is very hectic; it is something like the doomsday. Look at the following lines:

"The graves shall fly open and let you all in,

And the earth shall be emptied of mortal sin.

The fishes are silent deep in the sea, 
The skies are lit up like a Christmas tree,

The star in the West shoots its warning cry:

'Mankind is alive, but Mankind must die".

('Danse', in ibid: 61)

Now killing is at a distance. So, many people are killed. 'The graves shall fly open' to absorb all the dead. They are collective graves. Also 'the graves' do not open themselves. But here, Auden uses the graves as an agent for the verb 'fly'. Moreover, the verb 'fly' is an intransitive verb. It should not have an object. However, the poet uses 'open' in the position of the object to show that the graves will be opened widely. The poet introduces to us the star that 'shoots' and a 'cry' that performs the function of 'warning'. The point here is that Auden invites us to exert more effort and to think in order to solve such meaning perplexities.

Turning to 'Spain 1937', the researcher finds that semantic deviation abides in this poem. 'The nations combine each cry, invoking the life' is an example of semantic deviation. 'Nations' as an inanimate noun is incapable of combining or invoking anything. Also the inanimate 'life' is 'invoked', asked to 'intervene' and 'descend'. Then, it 'answers', 'replies', negotiates and asks questions. It gets involved in discourse and speaks, using the pronoun 'I'. Not only this, it also declares: 'I am Spain'. Spain is life. Also, we have 'stars' that are 'dead' and 'history' that 'says', 'helps' and 'pardons'. So, all these semantic deviations make us move far beyond the literal meaning of words to the hidden one.

\section{VII. 'September 1, 1939'.}

'September 1, 1939' is a poem written at the night of Hitler's invasion to Poland. That invasion terrified Europe and ended with the outbreak of World War II. The poem presents the general feeling of uncertainty and fear that spread all over Europe at that time. The poet, sitting in a tavern, describes this period as 'a low dishonest decade' offended with the 'odour of death' ('September 1, 1939') in ibid: 57). The poet recalls the past and condemns those who were responsible for the dissection of the Christian church, and the production of dictators. Also, he questions the Euphoric American dream that turned into a nightmare of 'international wrong' (ibid). He checks the faces of people in the bar, pretending courage and happiness, whereas they are not really so. He questions peoples' feeling of universal love that turned into selfish love. He criticizes the 'coming commuters' and 'helpless governors'. Finally, the poem ends with a little hope that 'whenever the Just / Exchange their messages', the poet 'may' get out of that mood of 'uncertainty and fear' and 'show an affirming flame (ibid).

\section{VII. a. Simple Repetition and Parallelism in 'September 1, 1939'.}

The word 'night' is repeated three times in the poem to reflect the 
general mood of anger and fear. Auden associates it to 'September', the title of the poem, as he says:

"The unmentionable odour of death

Offends the September night." (ibid)

Auden achieves parallelism by repeating the phrase structure 'noun+ and + noun'. Consider these examples: 'anger and fear', 'mismanagement and grief' and 'negation and despair'. This change of lexicon makes us think of anger, mismanagement and negation as primary causes of fear, grief and despair. Such a parallelism triggers us to search for the unsaid.

Also, the poet uses parallelism to describe how people sitting in the tavern try to resume their daily routine as if there is no war outside. Look at these lines:

"Faces along the bar

Cling to their average day:

The lights must never go out,

The music must always play" (ibid: 58)

The 'lights' and 'music' must 'never go out' and 'always play'. Lest they know the ugly truth or 'the struggle' as he called it in 'Spain 1937'. Moreover, 'helpless governors' who are unable to protect their people are involved in this dirty game of politics. They are depicted through parallelism also. Consider these lines:

"And helpless governors wake

To resume their compulsory game

Who can release them now, Who can reach the deaf,
Who can speak for the dumb?" (ibid: 59)

The repetition of the structure 'who+ the modal can+ transitive verb + object' is indicative. It shows that these helpless governors cannot release, reach or speak for their people. We realize the fact that even their people are not any better than their governors as they are deaf and dumb; to sum up, there is no connection at all between the governors and their people. Therefore, the people are subject to 'negation and despair' exactly like the poet himself who is created out of 'Eros' or lust and 'dust'.

VII. b. Discoursal Deviation in 'September 1, 1939'.

In this poem the poet, or the addressee, speaks to the audience, or the addressers, in a normal way. But the abnormal or deviant part is regarding the message he is delivering. The key words in this poem are in the phrase: "uncertain and afraid'. Nations, as well as people, suspect each other. They are also afraid of each other. That is why Auden does not state his message clearly as it should be. He does not tell us he is uncertain about what and afraid of what. He always refers to things indirectly.

In the second stanza, he mentions 'Luther' and 'Linz'. But he does not tell us that Luther was a German monk whose protestant dedications caused a lot of trouble to the Christian church in Europe. Luther subjected the church to the power of State. Also, Auden does not tell us 
that Linz is the birthplace of Hitler. It is the place where he was treated badly when he was young and that is why he grew up with psychological problems. According to Auden, suffering during early childhood produces dictators. Auden refers to Hitler as 'psychopathic God'. On his speech about 'Democracy', Auden tells us about 'Thucydides', the old Greek historian, and modifies his name with the modifier 'Exiled' to show us that this is the result of stating your opinion frankly about democracy and dictators. Then Auden proceeds to speak about America. But again, he never mentions it clearly. $\mathrm{He}$ tells us about its 'neutral air', the 'skyscrapers', 'Collective Man', 'Euphoric dream', 'imperialism' and 'the international wrong'. Of course, it is worth mentioning here that by the time of writing the poem, Auden has left England and migrated to America. At the beginning of World War II, America was not involved. It attempted to remain neutral. However, its people were not happy. They were 'lost' and 'afraid'. Then Auden moves and tells us about 'Nijinsky' and 'Diaghilev'. Also, he does not tell us that they were Russian dancers in love with each other. However, they did not get married because one of them betrayed the other. So, the betrayed one was driven 'mad'.

To recap, reading this poem, we find that Auden is condemning all sectors and people around him. $\mathrm{He}$ regards them all as 'unjust'. We do not know who is left as the 'Just'. Again, Auden leaves this discoursal message unclear.

\section{VII. c. Grammatical and Graphological Deviations in 'September 1, 1939'.}

The poem uses the simple present tense most of the time to present the duality between the generic and the specific. The poem starts with the pronoun 'I' that refers to the poet and his personal specific case. He says:

"I sit in one of the dives

On fifty-second street

Uncertain and afraid" (ibid: 57)

Then, the poet speaks about the effect of the current situation on himself and others by using the pronoun 'our'. He states that it is 'obsessing our private lives'. Then, he diagnoses the causes of psychological problems in personality by declaring that:

"Those to whom evil is done
Do evil in return"
(ibid)

The present tense shows that this is the poet's specific state as well as the others' state. Auden makes this grouping as he says: 'I and the public know/ What all schoolchildren learn' (ibid).

But the deviant grammatical part in this poem lies in Auden's use of inversion, ellipsis and lack of punctuation marks. Inversion resides in the following structures: 'out of the mirror they stare' and 'our world in stupor lies'. They should be: 'they stare out of the mirror. And 'our world lies in stupor'. Auden made these deviant changes in word order to 
depict the picture of the modern world. As for ellipsis, it appears many times in the poem. Firstly, the poet does not tell us he 'uncertain and afraid' of what. May be he is uncertain about the future and afraid of war. Secondly, on his use of the non-finite verbs like 'exiled' Thucydides for instance we do not know who exiled this man. Also, Auden regrets the absence of enlightenment. He says: 'The enlightenment driven away' (ibid). The poet deletes the verb 'be' for density's sake. Also the line 'the music must always play' incudes ellipsis. It should be 'the music must always be played'. But Auden wrote it likewise in order to achieve parallelism with the previous line 'the lights must never go out'. Such a structure helps us get the required sense of daily routine that the American people follow. These people and the poet behave this way for one purpose only. Auden says:

"Lest we should see where we are,

Lost in a haunted wood,

Children afraid of the night

Who have never been happy or good." (ibid)

Again, Auden proves his mastery of language. He uses ellipsis in the third line. It should be 'we are children afraid of the night'. But he deleted the subject and the verb. His deletion of the subject reflects the stubborn human nature that knows the ugly truth but refuses to confess its presence. And the phrase 'afraid of the night' should be preceded and followed by commas. But again, this conforms to children who are lost in the darkness of the night.

As for the graphological deviation, it is represented in the poem through the lack of question marks in some lines in the poem. Look at the following lines:

"But who can live for long

In an Euphoric dream;"

"Who can release them now;

Who can reach the deaf;

Who can speak for the dump?" (ibid: 59)

The poet asks rhetorical questions that do not need answers. Therefore, he uses the semi-column instead. On his description of the speech of politicians, Auden uses graphological deviation as he neglects the use of commas. He says:

"The windiest militant trash

Important Persons shout

Is not so crude as our wish:" (ibid: 58)

The second line should include the relative word 'which' and should be preceded and followed by commas. But Auden does so for the sake of density in meaning. Notice that he capitalizes the initial letter in the word 'Persons' to show that from outside they look great, but underneath they are empty and crude. They drag their people to war. Also, he capitalizes the first letter in the word 'Just'. He says:

"Ironic points of light

Flash out wherever the Just

Exchange their messages" (ibid) 
The deviant capitalization makes us ask about those who represent 'the Just' for Auden. He concludes that although he, himself, is not excluded from the un-just, yet he 'ma' be one of the just ones. But according to the general mood of the poem, the affirmative modal 'may' makes us think of its negative version 'may not' as well.

VII. d. Morphological and Lexical Deviations in 'September 1, 1939'.

Auden uses the prefixes 'un-', 'dis-', 'miss-' and the suffix '-less' in this poem for the sake of laconism. Such affixes are attached to open class lexical words only. Thus, he adds to the density of his poem. Look at these words: 'uncertain', 'dishonest', 'unmentionable', 'unearth', 'mismanagement', 'helpless' and 'defenceless'. He delivers his message in the shortest possible way. Also, he manipulates neologism through compounding. Check these examples: 'schoolchildren', 'skyscrappers', 'Collective Man' and 'the habitforming pain'. Also, he uses archaism as he calls Hitler 'God' and describes him as 'psychopathic'. Auden's use of non-finite verbs helps him create so many sentences that do not have verbs and agents. Not only this, he also succeeds in using them as adjectives and nouns. Examples: 'darkened lands', 'obsessing', 'exiled Thucydides', 'analysed', 'forming', 'lost', 'a haunted wood', 'repeating', 'dotted', 'composed', 'beleaguered' and 'affirming flame'. Such a device helps Auden to achieve ellipsis or disruption in so many occasions. This makes his poems more difficult and open to discussion.

VII. e. Semantic Deviation in 'September 1, 1939'.

There are many instances of semantic deviation in this poem. They are concomitant with meaning inconsistencies. In this poem Auden surprises us with many illogical pictures. Consider these examples: 'clever hopes expire', 'low dishonest decade', 'waves of anger and fear circulate', 'unmentionable odour of death', 'the elderly rubbish they talk', 'blind skyscrapers', 'conventions conspire', 'haunted wood', 'children afraid of the night', 'compulsory game', 'beleaguered by ... negation and despair' and 'affirming flame'.

\section{Conclusion}

This research paper has introduced a stylistic analysis of some selected poems of W. H. Auden's war poetry. Mainly, it dealt with 'O What is that Sound', 'Danse Macabre', 'Spain 1937' and 'September 1, 1939'. It tackled them from a foregrounding- backgrounding approach. The researcher's main objective was to put the deviant parts in these poems against the normal ones in them through a foregrounding-backgrounding relationship. In so doing, the researcher discovered that Auden was obsessed by war and its effects upon people, including himself, and the future of humanity in general. Auden was a keen follower of history. And his poems reflected it clearly. In ' $O$ What is that Sound', he said: 
"Perhaps a change in their orders

... But I must be leaving."

In this poem, he stated that the world is changing. And if you are to escape, you must move. In 'Danse Macabre', he said:

" Now matters are settled with gas and with bomb.

... For the Devil has broken parole and arisen,

... I shall come, I shall punish, the Devil be dead,

... 'Mankind is alive, but Mankind must die'

It's good-bye, dear heart, good-bye to you all."

Here he states that governors do not negotiate peacefully any more. Gas and bombs became the substitutes for words. War will destroy the whole wide world. The only hope left is to move and abandon luxurious life and laziness. For we are all sentenced to death. And in 'Spain 1937', he said:

"Yesterday all the past

... But today the struggle

... Tomorrow, perhaps, the future."

He told us that yesterday was great and full of victories and some few faults. Our history tomorrow will be determined today. So, today should be a great day full of work and struggle. Only this way, the future may be promising. It is left unknown. And in 'September 1, 1939', he said that he was " uncertain and afraid". Hitler broke his promise of the agreement of the Munich Conference. That behavior caused waves of anger and fear throughout the whole world. So, the future is foggy and clumsy.

The research presented all these feelings through a linguistic stylistic analysis of the poems. The researcher found that Auden used simple repetition, parallelism and deviation to achieve foregrounding. In so doing, he made us delve in the depths of his poems to understand them. And since the fact that the target of stylistics is to lead us to an objective evaluation of the writer and his texts; the researcher reached the conclusion that Auden is an omnipotent poet whose poems still deserve more work.

\section{References}

\section{Primary Sources}

Auden, W. H. 1976. The Collected Poetry of W.H. Auden. New York: Random House.

Blair, John. 1965. The Poetic Art of $W . \quad H$. Auden. Princeton: Princeton University Press.

Callan, Edward. 1983. Auden: a Carnival of Intellect. Oxford: Oxford University Press.

Currey, R.N. 1967. Poets of the 19391945 War. London: F. Mildner.

Fuller, John.1970. A Reader's Guide to $W$. H. Auden. London: Thames and Hudson.

Hoggart, Richard. 1957. W. H. Auden. London: Longmans.

McDiarmid, Lucy. 1984. Saving Civilization: Yeats, Eliot, and Auden between the Wars. Cambridge: Cambridge University Press. 
Rodway, Allan. 1984. A Preface to Auden. London and New York: Longman.

Rutherford, Andrew. 1989. The Literature of War. Macmillan Press.

Scarfe, Francis. 1947. Auden and After: the Liberation of Poetry 1930- 1941. London: George Routledge.

Sharma, Kedar N. "Spain by W. H. Auden: Summary."

BachelorandMaster, 3 July 2017, bachelorandmaster.com/britisha ndamericanpoetry/spainsummary.html

Tilak, Raghukul. 1986. Studies in Poets: W. H. Auden Select Poems. New Delhi: Rama Brothers.

\section{Secondary Sources}

Bennison's Neil. 1993. 'Discourse analysis, pragmatic and the dramatic character: Tom Stoppard's Professional Foul'. In Mick Short, ed. Language and Literature. Longman Group UK Linited Vol. 2, no. 2.

Blake, N.F. 1990. An Introduction to the Language of Literature. London: Macmillan.

Fowler, R. 1981. Literature as Social Discourse. London: Batsford Academic and Educational Ltd. 1987. Linguistic Criticism. Oxford: Oxford University Press.

Freeborn, Dennis. 1996. Style: Text Analysis and Linguistic
Criticism. London: Macmillan Press Ltd.

Panda, Ajaya Kumar. 2013. Style as Meaning: a Stylistic Analysis of W. H. Auden's Poems. Ph. D. dissertation. Sambalpur University. http://shodhganga.inflibnet.ac.in

Pennycook, Alastair. 2001. Critical Applied Linguistics: a Critical Introduction. Mahwah: Lawrence Erlbaum Associates.

Short, Mick. 1996. Exploring the Language of Poems, Plays and Prose. London and New York: Longman.

Simpson, Paul. 1997. Language through Literature. London and New York: Routledge.

Stageber, Norman C. and Oaks, Dallin. 2000. An Introductory English Grammar. Thomson Learning Inc.

Thornborrow, Joanna and Wareing, Shan.1998. Patterns in Language: An Introduction to Language and Literary Style. London and New York: Routledge.

Toolan, Michael. 2002. Language in Literature: An Introduction to Stylistics. Oxford University Press.

Traugott, Elizabeth Closs and Pratt, Mary. 1980. Linguistics for Students of Literature. New York: Harcourt Brace Jovanovich, inc.

Yule, George. 2006. The Study of Language. Cambridge: Cambridge University press. 